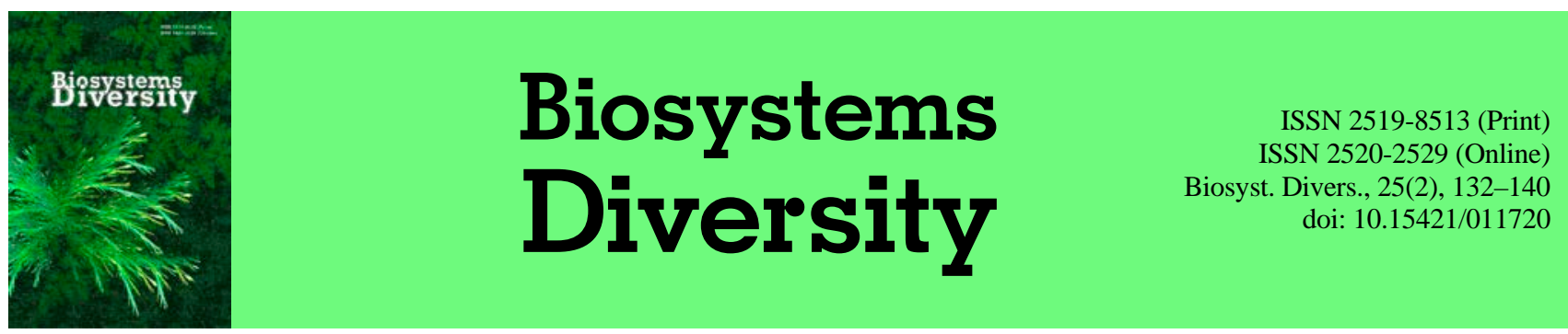

\title{
Pre-migratory congregations of Red-crowned (Grus japonensis), White-naped (G. vipio) and Hooded (G. monacha) cranes in the Muraviovka Park for Sustainable Land Use in 1992
}

\author{
P. I. Gorlov*, A. V. Matsyura** \\ *Crane Working Group of Ukraine, Melitopol, Ukraine \\ **Altai State University, Barnaul, Russia
}

\section{Article info}

Received 22.04.2017

Received in revised form 11.05.2017

Accepted 14.05.2017

*Crane Working Group of Ukraine, Kotsiubinskogo Str. 17, Melitopol, 72301, Ukraine. Tel.: +38-067-885-13-50. E-mail: petro-gorlov@mail.ru

**Altai State University, Lenin Str., 61,

Barnaul, 656000, Russia.

E-mail: amatsyura@gmail.com
Gorlov, P. I., \& Matsyura, A. V. (2017). Pre-migratory congregations of Red-crowned (Grus japonensis), Whitenaped (G. vipio) and Hooded (G. monacha) cranes in the Muraviovka Park for Sustainable Land Use in 1992. Biosystems Diversity, 25(2), 132-140. doi:10.15421/011720

The autumn pre-migratory concentrations of Red-crowned, White-naped and Hooded Cranes were studied in the Muraviovka Park for Sustainable Land Use and Environmentla Education (Tambov District, Amur Region, Russian Federation) during 23.08-29.09.1992. We counted 292 Hooded Cranes, 34 White-naped Cranes, and 17 Red-crowned Cranes during the study period. We also marked specific differences in the behaviour of the birds connected with their readiness for migration. The Hooded Cranes showed the greatest readiness for migration. We observed mutual flights, overnight stays, and feeding of adult birds and family groups in their flocks. This was not the same in the flocks of Whitenaped Cranes. However, the average number of birds in the flocks of White-naped Cranes had increased by the end of our observations due to new families joining the general flock. The family parties of the Red-crowned Crane and adult birds without young individuals stayed apart from each other and from other crane species during the whole observation period. We registered the autumn departure of Hooded Cranes in late September, the migratory departure of White-naped Cranes in the middle of October, and the Red-crowned Cranes left the area in the first half of November. The breeding period for all crane species starts at the same time: the third decade of April - the beginning of May. The young of the studied crane species differ significantly in the period of time before fledging: Hooded Cranes - 55-60 days, White-naped Cranes - 6570 days, and Red-crowned Cranes - 70-75 days because of their specific differences in the ratio of size to weight (1: 1.3 : 1.7). Thus, the time difference between the Hooded and Red-crowned Cranes is about 2-3 weeks. We suggest that this is the main reason that determines the differences between these species in the timing of the the start of autumn migration.

Keywords: autumn pre-migration gatherings; number of birds in a flock; breeding season; birds’ behaviour

\section{Предотлетное скопление японского (Grus japonensis), даурского (G. vipio) и черного (G. топасha) журавлей в 1992 г. на территории Муравьевского парка устойчивого природопользования}

\author{
П. И. Горлов*, А. В. Мацюра** \\ *Украинская рабочая группа по журавлям, Мелитополь, Украина \\ **Алтайский государственный университет, Барнаул, Россия
}

В период 23.08-29.09.1992 г. изучены осенние предотлетные скопления японского, даурского и черного журавлей на территории Муравьевского парка устойчивого природопользования (Тамбовский р-н Амурской обл., Россия). Максимальные численности птиц составили для черного журавля - 292 особей, даурского - 34 и японского - 17 особей. Отмечены различия в поведении птиц, связанные с их готовностью к миграции. Наиболее готовыми к миграции были черные журавли. В их скоплении отмечены совместные перелеты, ночевки и кормление взрослых птиц и семей с молодыми. У даурского журавля эта связь менее тесная, однако, к концу наших наблюдений отмечалось увеличение среднего числа птиц в стаях, что свидетельствует о процессе вливания семей в общую группу. Семьи японского журавля и взрослые птицы без молодых весь период наблюдений держались обособленно друг от друга и от других видов журавлей. Осенний отлет черных журавлей по нашим наблюдениям произошел в конце сентября. Даурский журавль покидает район исследований в середине октября, а японский - в первой половине ноября. Старт гнездования у этих видов происходит в схожие сроки: третья декада апреля - начало мая. Из-за неравного соотношения размеров и массы у особей этих видов (1 : 1,3 : 1,7$)$ молодые поднимаются на крыло с очень заметным расхождением по времени: у черных - в 55-60-дневном, у даурских - 65-70-дневном, у японских журавлей - в 70-75-дневном возрасте. Таким образом, различия между черным и японским журавлями составляет 2-3 недели. Вероятно, эта разница и лежит в основе отмеченных отличий в поведении этих видов в период предотлетных скоплений. 


\section{Введение}

Все три вида журавлей находятся под охраной как на международном, так и государственном уровнях в России и большинстве стран, входящих в ареалы этих птиц (Higuchi et al., 2004; Marsh and Trenhan, 2008; Yuxiang et al., 2012; Gilber et al., 2016; Heim and Suanjak, 2016; Butler, 2017). Численность всех из них низка, имеет тенденцию к снижению, а наиболее многочисленный черный журавль относится к наименее изученным видам Палеарктики (Gil-Weir et al., 2012; Liying and Hongfei, 2012; Butler, 2013; Wang et al., 2014; Sun et al., 2015; Gilber et al., 2016; Zhou et al., 2016).

Уникальность Муравьевского парка состоит в природных условиях, благоприятных для пребывания здесь журавлей, среди которых японский и даурский - гнездятся, и вместе с черным образуют осенние скопления, в которых изредка можно встретить стерха (Grus leucogeranus), серого (G. grus) и журавля красавку (Antropoides virgo) (Heim and Suanjak, 2016).

Очевидно, статус всех видов требует специальных исследований их гнездовой биологии, миграций, зимовок, как осно- вы для мер охраны. Анализ литературы показывает дефицит таких знаний (Nosachenko and Smirenskiy, 2008; Heim and Suanjak, 2016; Amur Bird Project..., 2016), что побудило нас опубликовать данные 1992 г., которые ретроспективны, однако могут служить сравнительным материалом современным исследованиям, которые проводятся на территории Муравьевского парка в рамках Amur Bird Project с 2011 года (Amur Bird Project..., 2014; 2015).

\section{Материал и методы исследований}

В период 23.08-29.09.1992 г. изучены осенние предотлетные скопления японского, даурского и черного журавлей на территории Муравьевского заказника (Тамбовский р-н Амурской обл.), где планировалось создание Муравьевского парка устойчивого природопользования, что и произошло в 1996 г. (парк находится в южной части долины рек Зея и Бурея, в 65 км на юго-восток от Благовещенска, площадь его составляет 52 км², координаты - 4957'29"N, 127³6'47"Е (рис. 1).

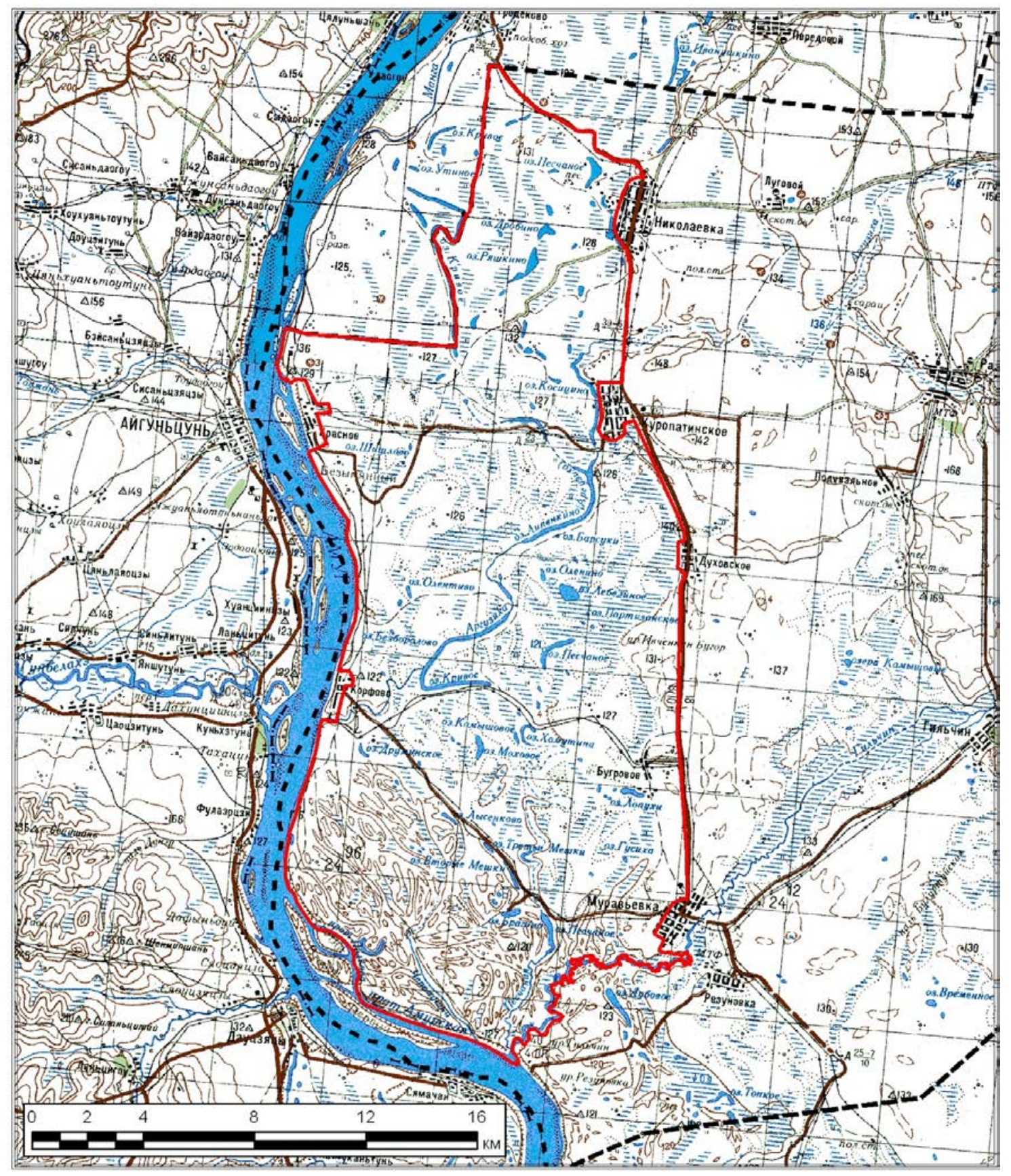

Рис. 1. Схема расположения парка «Муравьевский»: красным цветом показана граница парка 
Основным местом стационарных наблюдений были окрестности брошенного с. Бугровое, где ныне расположена усадьба парка. Кроме того, осуществлены кратковременные выезды в удаленные точки Муравьевского парка (села Красное, Корфово, Куропатино, Духовское, Гильчин).

За основу описания поведения журавлей в скоплениях взята методика, предложенная Ю. Э. Кеспайком. В местах ночевок журавлей наблюдения проведены за полчаса до рассвета и до отлета последних птиц утром, а также вечером за 2 часа до сумерек и до полной темноты. В середине дня собрана фрагментарная информация о местах кормления птиц и дальности их разлетов. Использовался бинокль БПЦ 8 . Общая продолжительность хронометрирования поведения журавлей составила 200 часов. Учитывая давность исследований и произошедшие с тех пор климатические изменения, влияющие на жизненные ритмы птиц, целесообразно охарактеризовать температуру воздуха и количество осадков в период наших наблююдений, которые представлены на рисунках 2-3 и взяты нами из архива погоды (Archiv..., 2017). Географические названия приводятся в их употреблении местным населением. Статистическая обработка осуществлена в программах Excel и Statistica (модуль Basic Statistic).

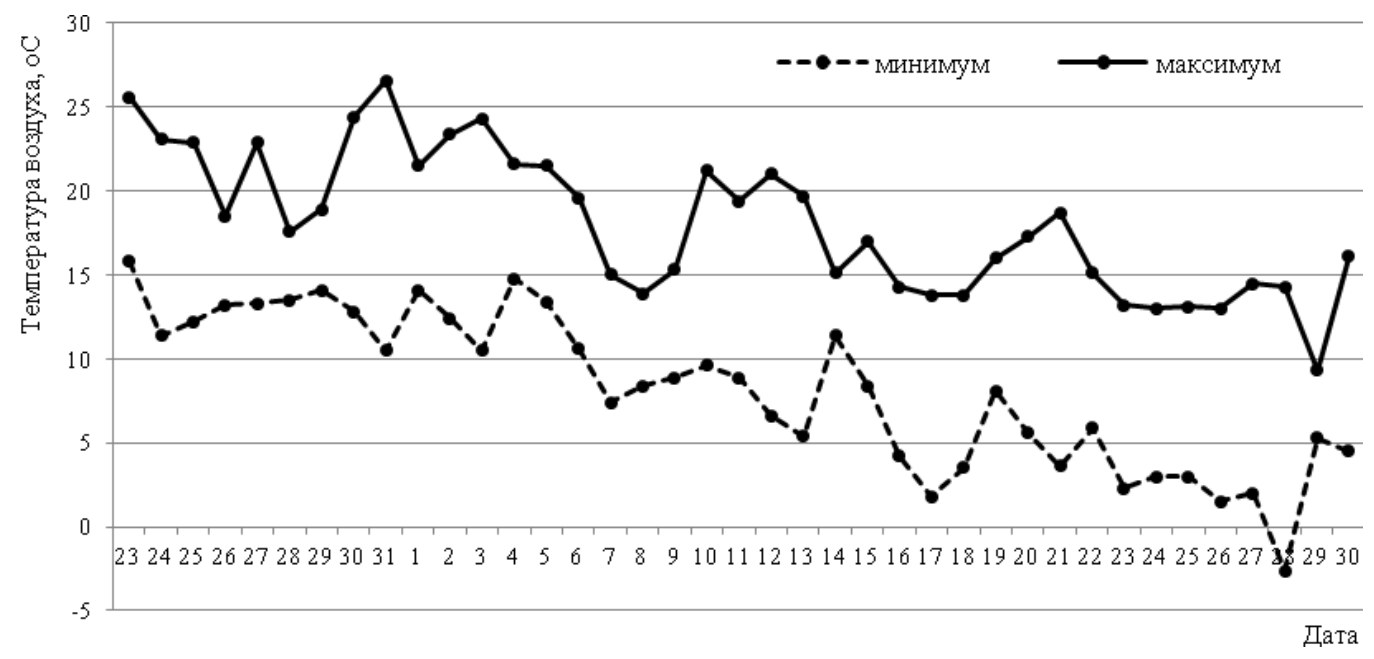

Рис. 2. Температура воздуха в Благовещенске в августе-сентябре 1992 г.

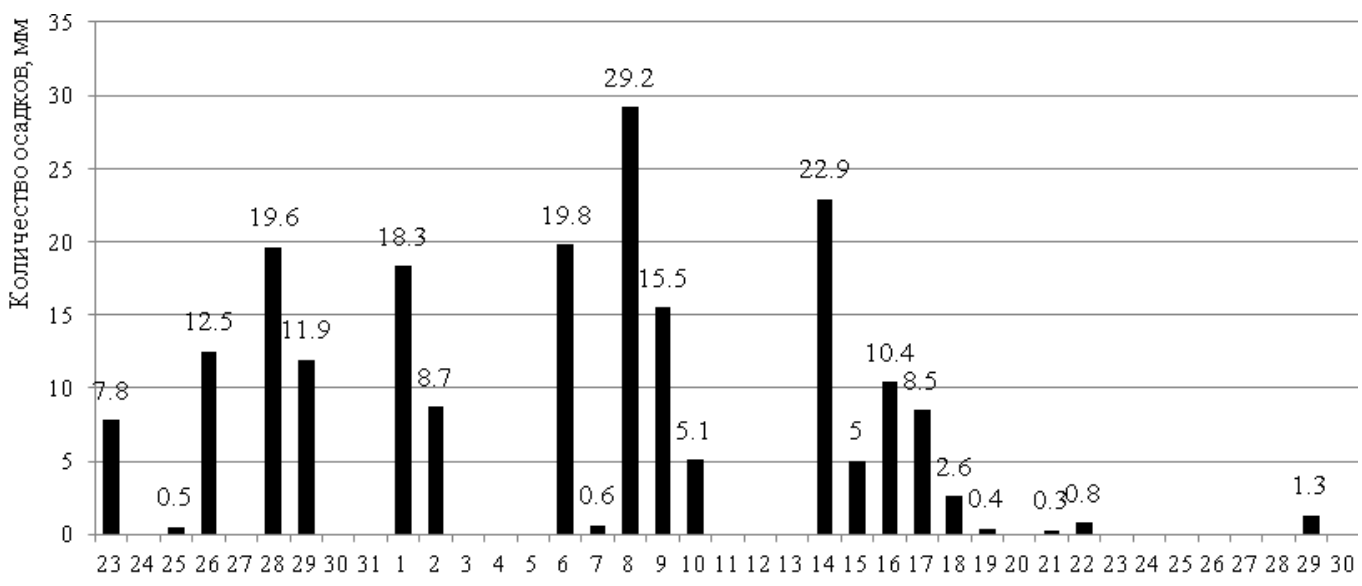

Дата

Рис. 3. Осадки в виде дождя в Благовещенске в августе-сентябре 1992 г.

\section{Результаты и их обсуждение}

\section{Черный журавль}

Суточная активность

С наступлением утренних сумерек, птицы в месте ночевки проявляли беспокойство, выражающееся в одиночных криках, чистке оперения, подпрыгиваниях, частых взмахах крыльев и коротких конфликтах. С восходом Солнца беспокойство птиц усиливалось, достигая предела к отлету первой группы к местам кормежки. Они разлетались группами в 7-9 ос. или отдельными семьями в три различные места кормежки. Некоторые группы, отлетев на 100-150 м от места ночевки, снова садились в пределах болота, после чего улетали на сельхозполя. С 10 по 25.09 точно установлены места утренней кормежки, отстоявшие от мест ночевки в 900-5 500 м. Вылет на них происходил в этот период с 6 ч 55 мин до 7 ч 20 мин. Журавли кормились здесь на: свежескошенных злаковых культурах с высотой стерни 4-8 см и остатками зерна в валках; скошенной кукурузе; многолетних травах (сенокосы). Наибольшее предпочтение журавли отдавали полям первого типа. Так, 15.09. из 263 учтенных накануне особей, 210 (79,9\%) кормились на поле скошенной пшеницы. В середине дня, в среднем к 13 ч 32 мин (n = 8; lim: 11 ч 00 мин - 14 ч 50 мин) большая часть журавлей парила высоко в небе, негромко, но часто крича. После 30 40 мин парения, основная группа, состоящая в среднем из 98,3 ос. $(\mathrm{n}=6)$, рассыпалась на более мелкие со средним числом птиц 5,4 oc. $(\mathrm{n}=33$; lim: $1-17)$, и разлеталась на дневной отдых. Днем птицы иногда оставались на кормовых полях, чаще же рассредоточивались по болоту, на котором и ночевали. Во время дневного отдыха журавли чистились, подолгу осматривались, если позволял грунт - садились. Такими же небольшими группами птицы улетали на вечернюю кормежку между 16 ч 00 мин и 16 ч 50 мин. Вечером во все дни наблюдений черные журавли кормились на поле скошенной пшеницы, расположен- 
ном в 5-7 км от места ночевки, около канала между селами Гильчин, Духовское, Муравьевка. Сбор на ночевку птицы начинали в среднем в 19 ч 02 мин (n = 11; lim: 17 ч 15 мин - 20 ч 10 мин) и заканчивали к 19 ч 58 мин (n = 10; lim: 18 ч 45 мин - 20 ч 15 мин), на что уходило в среднем 45 мин $(\mathrm{n}=10$; lim: 10-
109 мин). Продолжительность сбора журавлей на ночевку к концу сентября уменышалась вместе с сокращением долготы дня (рис. 4). Схожую тенденцию в Муравьевском парке отмечали и осенью 2006 г., правда без указания о каком из трех видов журавлей идет речь (Nosachenko and Smirenskyi, 2008).

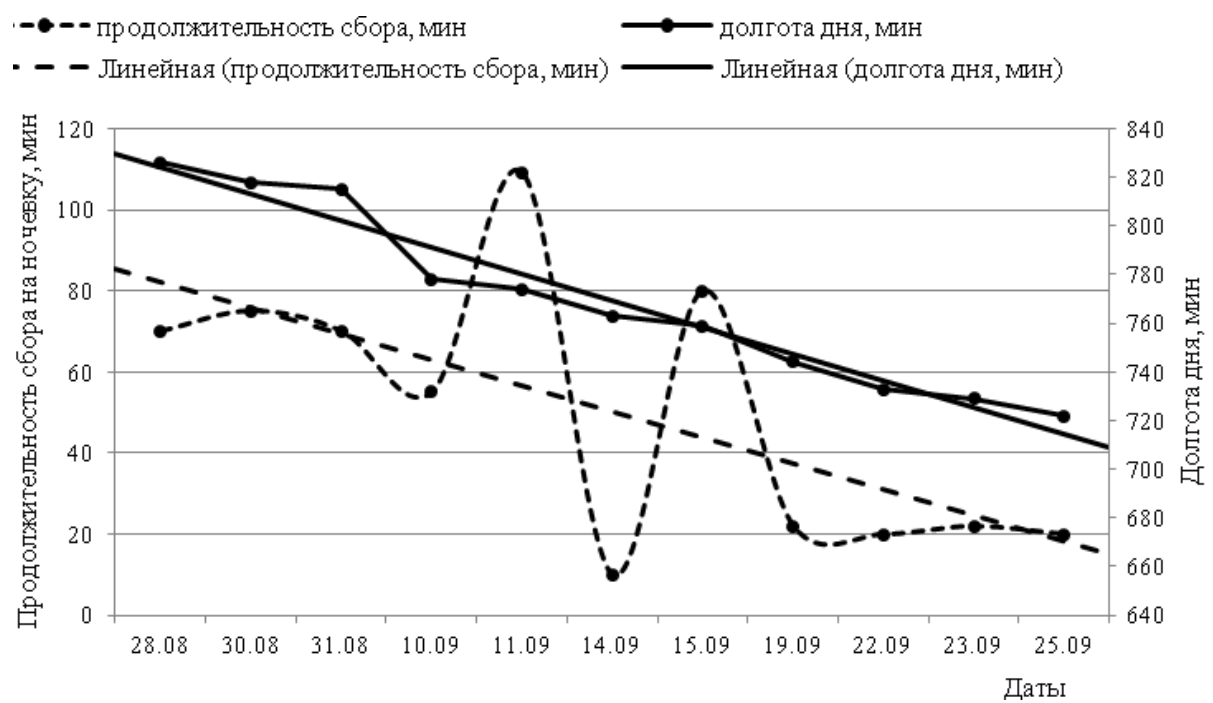

Рис. 4. Долгота дня и продолжительность сбора на ночевку черных журавлей

Также в период наблюдений сокращалась продолжительность дневного парения журавлей. Так, 29-31.08 черные журавли интенсивно крича, парили высоко в небе в интервале 11 ч 00 мин - 13 ч 30 мин. К середине сентября (11.09) парящие журавли отмечены в 12 ч 50 мин - 13 ч 45 мин, а 20.09 - около 20 птиц наблюдались в небе в 14 ч 30 мин - 14 ч 50 мин. После этих дат, парящие журавли не отмечены. Специальные наблюдения за осенним скоплением серого журавля на Центральном Сиваше (Украина) объясняют этот феномен фиксированной продолжительностью суточного кормления, как следствие вынужденным сокращением времени на дневное парение и перелеты к месту ночевки на фоне укорачивающегося дня (Gorlov, 1998).
Погода и периодичность ночевок

За период наблюдений черные журавли сменили место ночевки, что, по-видимому, произошло из-за прилета северных птиц и увеличения их общей численности, повлекшей необходимость выбора более обширного участка болота для ночевок. Вторая причина - открытие охотничьего сезона (29.08.1992) на водно-болотную дичь и увеличение фактора беспокойства от охотников, собиравшихся недалеко от прежнего места ночевки. Так, с 23.08 по 3.09150 журавлей ночевали в крайней юго-восточной части болота (рис. $5, A$ ), а с 4.09 и до конца наблюдений (28.09) птицы ночевали между озер Лебединое и Песчаное в 1700 м к центру болота (рис. 5, $B$ ).

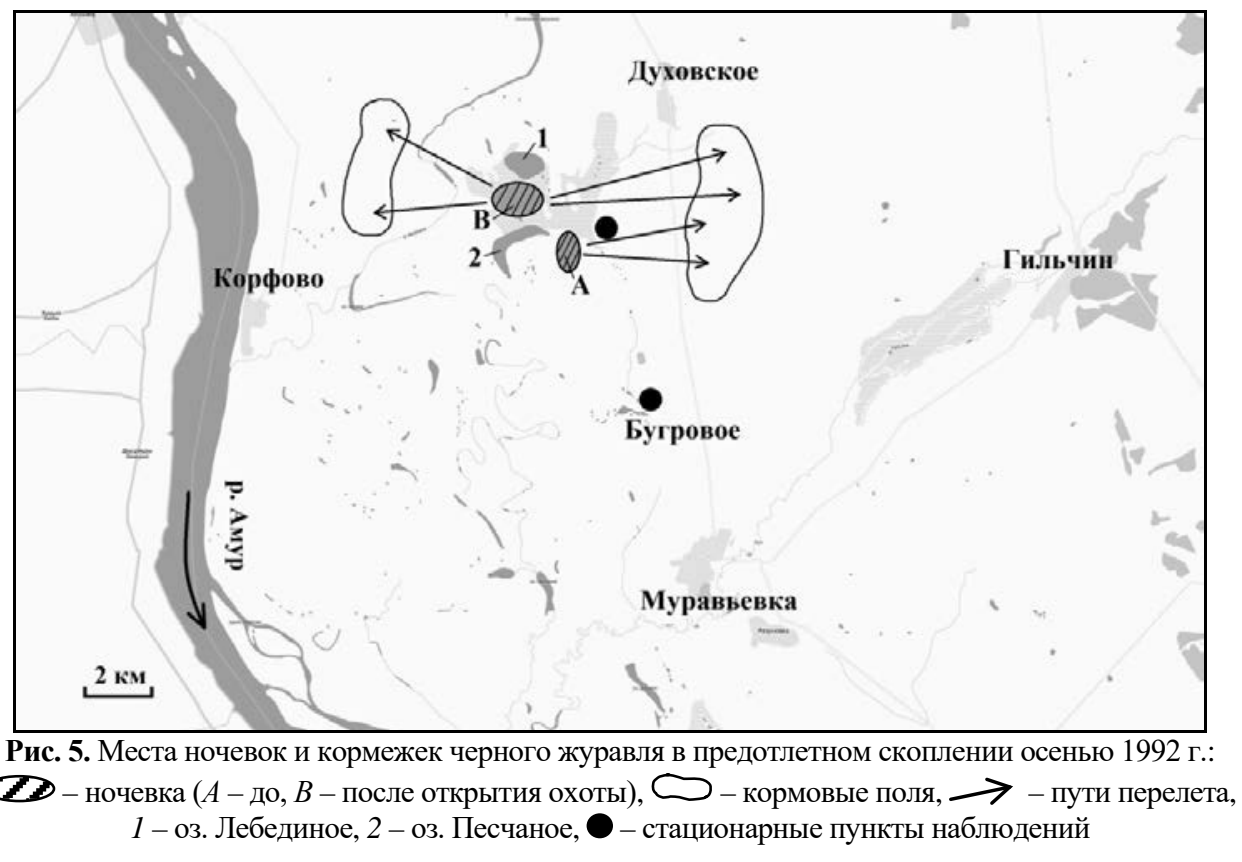

За 37 дней наблюдений 15 дней шел дождь, 4 раза - ночью. Слабый моросящий дождь (5 дней), как и осадки разной интенсивности не препятствовали перелету журавлей на ночевку, однако, задерживали сбор. Так, 14.09 во второй половине дня начался сильный дождь, продолжавшийся до темноты. В это короткое время выпало почти 23 мм осадков (рис. 3). Поздний отлет журавлей на ночевку с кормовых полей начался в 20 ч 05 мин и продолжался всего 10 мин. Схожую картину мы наблюдали в скоплении серых журавлей (Grus grus) на Центральном Сиваше (Джанкойский р-н, Крым) в 1993 г., когда 
ливневый дождь и штормовой ветер «держали» птиц на кормовых полях до самой темноты (Gorlov, 1998). Существенное влияние осадки и температура воздуха оказывают на бюджет времени и сроки размножения птиц и в гнездовое время, что показано для серого (Vinter and Gorlov, 2003) и черного (Vinter et al., 2015) журавлей.

Еще один массовый старт на ночевку отмечен 10.09, когда в не охотничий день группа браконьеров на двух автомобилях на территории Муравьевского заказника открыла интенсивную стрельбу по водоплавающей дичи. Около 200 журавлей (из 258) в 19 ч 20 мин перелетела в традиционное место ночевки, остальные, небольшими группами тянули до 20 ч 15 мин.

Динамика численности в скоплении

За период наблюдений отмечены три волны роста численности журавлей и две четко выраженных волны отлета. Первое двукратное увеличение численности птиц произошло 31.08 после открытия охоты 29-30.08. Вероятно, повышенное беспокойство со стороны охотников, объединило разрозненные группировки местных черных журавлей. Однако постоянное увеличение скопления, продолжавшееся до 10.09, когда численность птиц достигла 260 ос., говорит скорее о прилете журавлей с севера. В интервале 10-15.09 число птиц было стабильным. Недоучет 14.09 связан с усилением пресса охоты в выходные дни (12-13.09) и большей рассредоточенностью журавлей по кормовым полям. Свою роль сыграл и сильный дождь во второй половине дня 14.09. Резкое похолодание 17-19.09, по-ви- димому, спровоцировало первый отлет птиц (около 100 ос.). В эти же дни появились мигрирующие стаи гусей (первые отмечены 11.09). К 21.09 в скоплении появились птицы, которые утром 23.09, набрав высоту, улетели в юго-восточном направлении, что говорит о кратковременной остановке тут транзитных мигрантов. В традиционном месте ночевки 25.09 было учтено лишь 49 птиц (рис. 6). Отметим, что в третьей декаде сентября почти каждую ночь отмечались легкие заморозки на почве.

Возраст птиц в скоплениях

Поскольку часть семей держалась обособленно от групп, удалось учесть число молодых у 24 семей. В 13 из них $(54,2 \%)$ было по 1, в 11 (45,8\%) - по 2 молодых. Итак, у 24 успешно размножавшихся пар было 35 молодых, поднявшихся на крыло и преодолевших часть миграционного пути, что составляет 1,46 молодых на пару.

Величина и динамика групп в скоплениях

Группы разной величины встречены 251 раз. Отмечены одиночки и объединения от 2 до 140 птиц. Количество птиц в группе вероятно зависело от того, насколько полно произошло «вливаниө> семейных групп в большие по численности объединения Первой ступенью к сегрегации у семей было слияние в группы из 6 (две пары по одному молодому в каждой), 7 (2 семьи с 1 и 2 молодыми) и 8 (2 пары по 2 молодых в каждой) птиц. Чаще всего встречены «четверки» $(17,1 \%)$, в большинстве случаев представлявшие собой семейную группу, и объединения от 11 до 20 птиц (13,9\%), в которых семьи с молодыми представлены слабо (рис. 7).

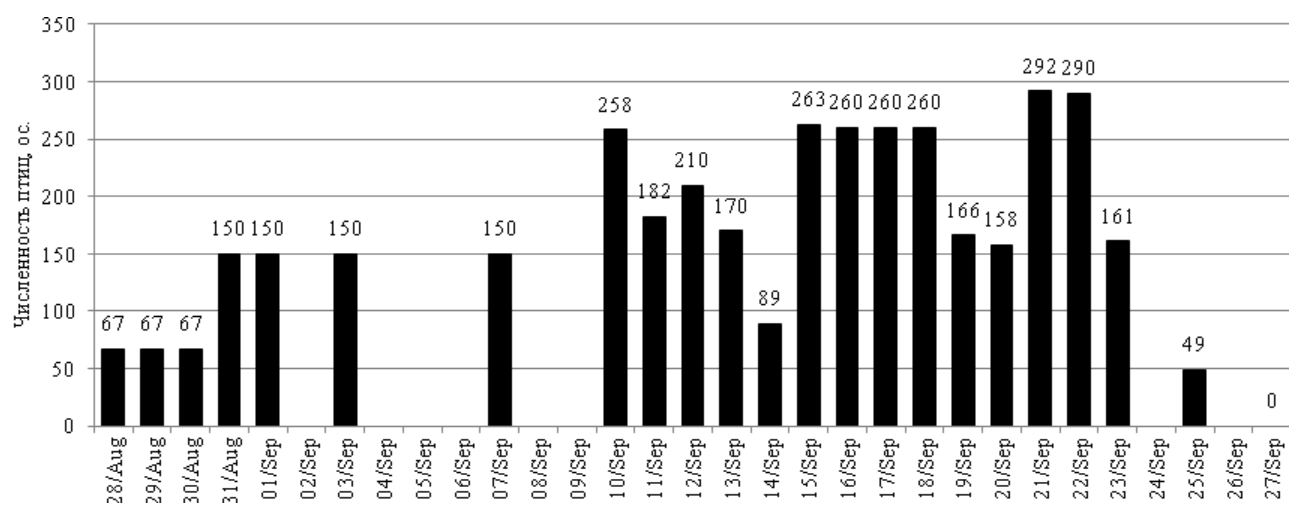

Рис. 6. Динамика численности черных журавлей в месте ночевки предотлетного скопления

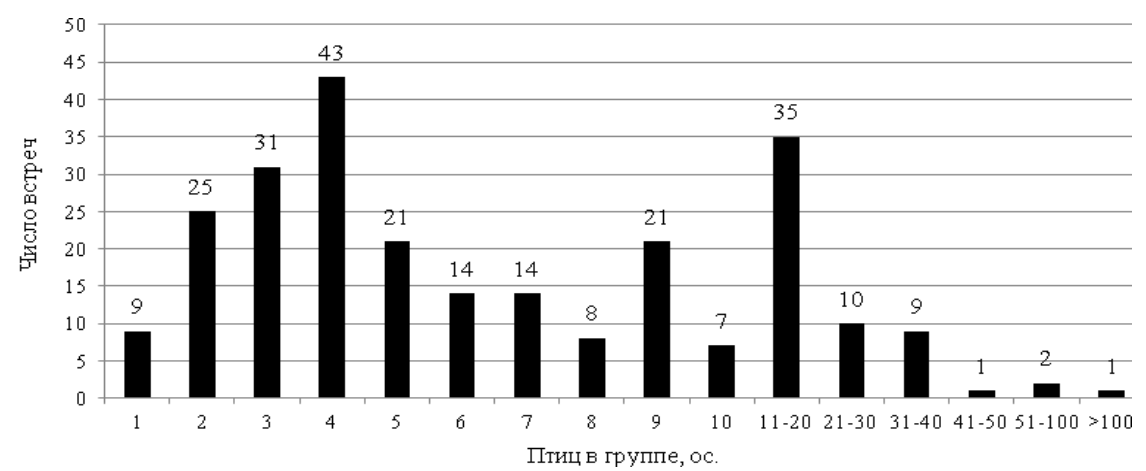

Рис. 7. Встречи групп черного журавля

По наблюдениям миграции черных журавлей в Архаринской низменности (Andronova and Andronov, 2008) в 200 км юго-восточнее нашего района исследований установлено, что размер стай на осеннем пролете в августе очень схож размером групп в Муравьевском предотлетном скоплении в сентябре. Среднее число птиц в группах при дневных перемещениях (исключая группы дневного парения) - 5,54 + 3,6 (n = 56; lim: 1 $\left.17 ; \mathrm{C}_{\mathrm{v}}=65,9 \%\right)$, а среднее число птиц при сборе на ночевку 9,7 $\pm 11,0$ (n = 194; lim: 1-97; $\mathrm{C}_{\mathrm{v}}=114,2 \%$ ). Таким образом, сбор на ночевку у черных журавлей достоверно проходил более дружно $\left(\mathrm{t}_{\text {эмп }}=2,8 ; \mathrm{P}<0,01\right)$. Интересно сравнение графиков динамики общей численности журавлей и среднего числа птиц в группах, следующих на ночевку. Показательно, что перекрывание графиков наблюдалось в период миграционного отлета первой группы птиц. Не исключено, что увеличение среднего числа особей в группах, идущих на ночевку, явилось «сигналом к старту» (рис. 8). В настоящее время, численность журавлей в скоплениях изменяется вследствие высокого беспокойства птиц во время уборки кукурузы, обработки полей после ее скашивания и наличия доступного корма (Dugintsov, 2015). Это, скорее всего, также является основной причиной постоянной смены мест ночевок, которые находятся вблизи кормовых участков, однако на максимальном удалении от человека. 


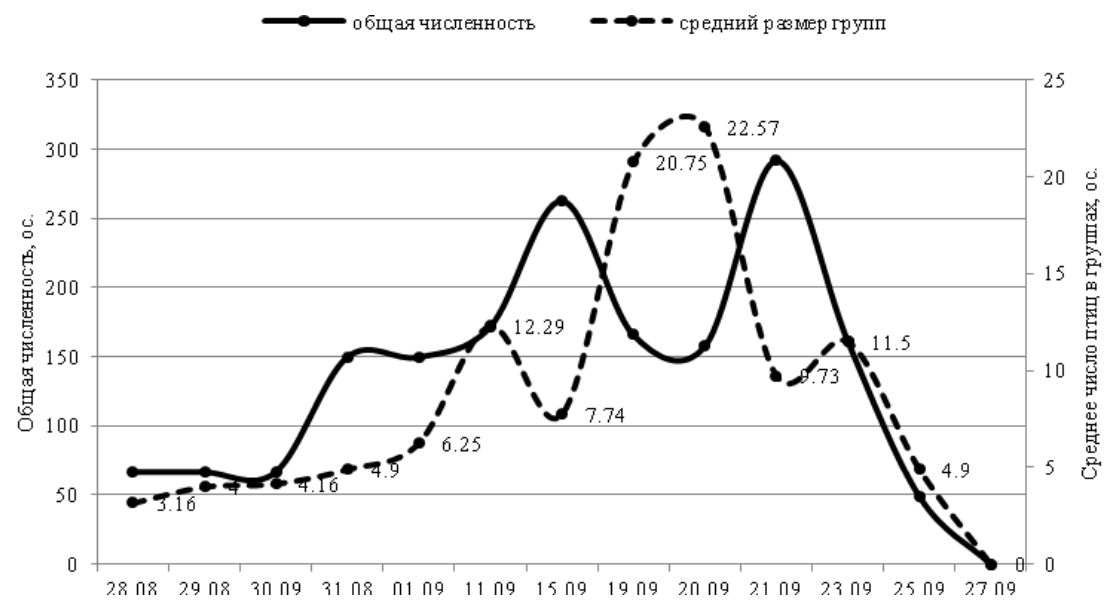

Рис. 8. Численность и среднее число черных журавлей в группах, следующих на ночевку

\section{Даурский журавль}

Суточная активность

C наступлением дня птицы улетали на близлежащее от места ночевки поле скошенной пшеницы с разбросанными по нему копнами соломы. Здесь журавли кормились первые 3 4 часа светлого времени, затем семейные группы возвращались на болото, где держались обособленно. Основная группа, не имеющая в своем составе молодых, либо рассеивалась по кормовому полю и отдыхала, либо также слетала на болото. Расстояние между кормовым полем и местом дневного отдыха составляло от 150-200 до 1500 м. К отлету на вечернюю кормежку птицы сближались и заметно возбуждались: взмахивали крыльями, часто кричали, подолгу осматривались с высоко поднятыми головами. После этого все птицы взлетали, перелетали на кормовое поле, где семьи садились в стороне от основной группы. Некоторые из семей спустя 10-15 мин пешком, постоянно кормясь, соединялись с основной группой. В среднем вылет на вечернюю кормежку происходил в 16 ч 45 мин ( $\mathrm{n}=5$; lim: 16 ч 34 мин - 17 ч 06 мин).

На ночевку птицы начинали собираться в среднем в 18 ч 30 мин ( $=11$; lim: 17 ч 30 мин - 19 ч 09 мин), а заканчивали сбор в среднем в 18 ч 56 мин $(\mathrm{n}=11$; lim: 18 ч 50 мин - 19 ч 17 мин), на что им требовалось в среднем 38 мин ( $=11$; lim: 3-107 мин). Интересно, что разница между окончанием сбора на ночевку даурских журавлей и началом сбора черных составила 10-12 мин (см. данные выше). До середины сентября даурские журавли кормились на одном поле скошенной пшеницы, предпочитая пониженные участки, пересеченные оврагами, поросшими кустами лещины обыкновенной (Corylus avellana (L.) H. Karst., 1881) и шиповника даурского (Rosa davurica Pall., 1788). В тех местах, где лежали скошенные валки, была обильно рассыпана пшеница, давшая зеленую поросль, привлекавшую журавлей.

Во второй половине сентября даурские и черные журавли кормились вместе в 2,0-2,5 км от места ночевки; причина смены кормовых полей не понятна.

Ночевали журавли на низинном травяном болоте в юговосточной части Муравьевского заказника (рис. 9). Высокая трава в сочетании с небольшой глубиной воды позволяли журавлям успешно скрываться и контролировать окружение. К наступлению темноты семьи, находившиеся в течение дня в среднем в 104 м (n = 5; lim: 50-200 м) от основной группы, сокращали расстояние в среднем до 23 м (n = 5; lim: 10-30 м), либо дважды сливались в одно скопление.

\section{Периодичность ночевок}

Открытие сезона охоты на выбор ночевочного места даурских журавлей оказало меньшее влияние, чем на черных: птицы сместились внутри болота на 170-200 м. Лишь 10.09 уже собравшихся на ночевку журавлей потревожили два проезжавших мимо всадника. Птицы, скопление которых было сформи- ровано в непосредственной близости от первой надпойменной террасы, по которой проезжали всадники, перелетели вглубь болота на 600-700 м, а к следующей ночи собрались в прежнем месте.

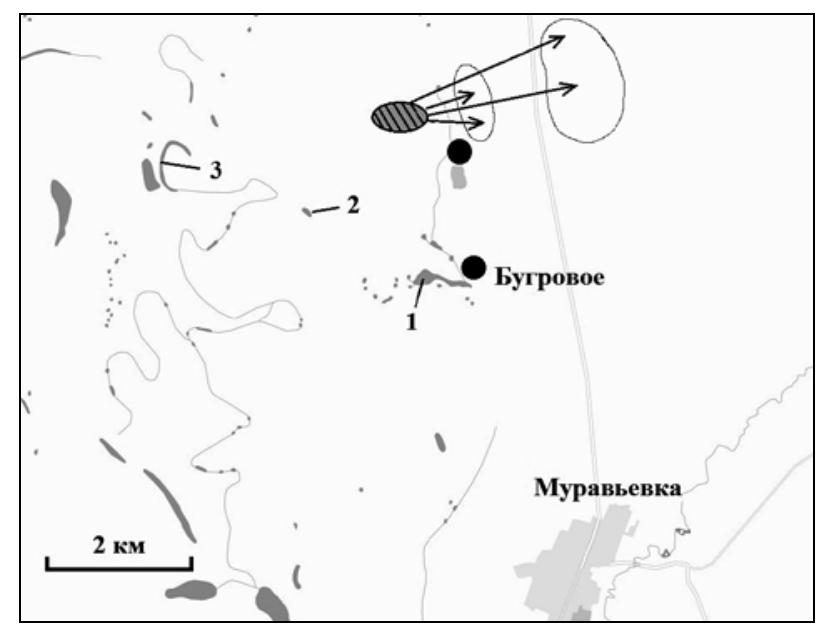

Рис. 9. Места ночевок и кормежек даурского журавля в предотлетном скоплении осенью 1992 г.: - ночевка;

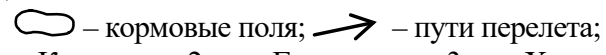

1 - оз. Капустиха; 2 - оз. Гальянистое; 3 -оз. Хомутина;

- стационарные пункты наблюдений

Динамика численности и возраст птии в скоплении

С 28.08 по 28.09 численность даурских журавлей была стабильной и составляла 34 птицы. Хорошие условия наблюдения за птицами позволили выделить семьи с молодыми. Так, в 1992 г. успешно размножались 5 пар у которых было 7 молодых (2 семьи по 2 молодых в каждой и 3 семьи по 1 молодому), что составляет 1,4 на пару. Здесь же держалась группа из 17 птиц во взрослом наряде. Процесс вливания семей в общее скопление проходил следующим образом. Семья с одним молодым примкнула к общей группе 31.08 , а остальные 4 семьи держались обособленно. В этот же день замечены территориальные конфликты между самцом из семьи с двумя молодыми и взрослой птицей из общей группы. Конфликт закончился выдворением последней с охраняемой семьей территории. К 10.09 в общей группе уже были две семьи (в каждой по одному молодому), а 23.09 даурские журавли кормились, перелетали и ночевали общей группой. Показательно, что первыми влились в общую группу семьи с одним молодым, а семьи с двумя молодыми позже избавлялись от «остаточной территориальности».

Величина и динамика групп в предотлетном скоплении

Группы разной величины встречены 25 раз. Помимо одиночек отмечены объединения от 2 до 30 особей (рис. 10). В сен- 
тябре чаще встречались группы в 3-4 птицы, составившие $48 \%$ от общего числа встреч, что сравнимо с данными для Архаринской низменности, где такой показатель равен 34,8\% (Andronov, 2008). Отмечены перелеты 30 групп птиц. Среднее число особей в дневных группах $-4,47 \pm 3,31$ (n = 17; lim: $1-$ 14; $\mathrm{C}_{\mathrm{v}}=74,2 \%$ ), в группах, летящих на ночевку, недостоверно больше - 7,62 \pm 5,87 ( $=13$; lim: 2-23; $\left.\mathrm{C}_{\mathrm{v}}=77,0 \%\right)$. На рисунке 11 видна тенденция к увеличению числа особей в группе, что вероятно отражает вливание семей в общую группу.

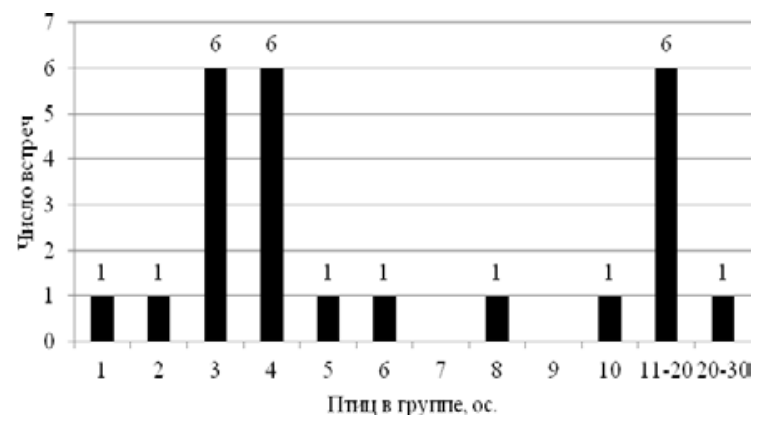

Рис. 10. Встречи групп даурского журавля

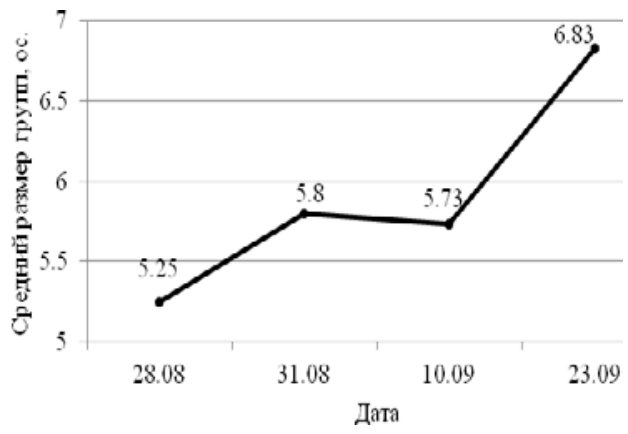

Рис. 11. Среднее число птиц в группах даурских журавлей

\section{Японский журавль}

Суточная активность

До окончания наблюдений птицы держались семьями и отдельными парами. Отмечены три места ночевки. В разное время от 6 до 9 птиц держались в центральной части Муравьевского заказника в ложбине, шириной 200 м, с высокой травой и влажной почвой. Ложбина граничила с большим полем скошенной пшеницы и небольшим участком сенокоса. Одна пара нерегулярно держалась на травяном болоте у окраины с. Муравьевка. Постоянное место ночевки - на болоте в 1 км юго-западнее оз. Капустиха, практически напротив с. Бугровое (рис. 12).

С рассветом птицы перелетали или переходили на поля, расположенные по соседству. После утреннего кормления японские журавли нередко парили высоко в небе $(31.08-11$ ч 30 мин - 6 птиц; 11.09 - 14 ч 00 мин - 3 птицы; $12.09-13$ ч 00 мин - 2 птицы), но чаще отдыхали днем на местах ночевок. К 17 ч 30 мин - 18 ч 20 мин некоторые пары и семьи с молодыми вылетали на вечернюю кормежку и в среднем к 19 ч 53 мин (lim: 19 ч 41 мин - 20 ч 17 мин) возвращались на ночевку. Максимальное расстояние от места ночевки до кормового поля 800 м, в противоположность черным и даурским, японские журавли в это время почти не летали. Даже согнанные человеком, они отлетали лишь на 300-500 м вглубь поля или болота. Большую часть дня разрозненные группы японских журавлей проводят на болоте, что также отмечали Nosachenko and Smirenskiy (2008).

Погода и периодичность ночевок

Со второй половины сентября постоянным местом ночевки стал второй участок, западнее оз. Капустиха; нередко там же птицы проводили и день. Так, 14.09 (сильный дождь) птицы корми- лись и ночевали на месте ночевки. Вечером 19.09 проезжавший трактор испугал птиц, собравшихся на ночь, после чего журавли перелетели на другое место, но 20.09 снова ночевали здесь.

Динамика численности и возраст птич

Весь период наблюдений численность японских журавлей была постоянной (17 птиц). По словам районного охотоведа Н. Д. Никулина - это 6 местных гнездящихся пар с молодыми. Удалось учесть три семьи с 5 молодыми (в двух семьях по 2 и в одной - 1 молодой), что составило 1,67 молодых на успешно размножавшуюся пару. В отличие от молодых птиц в семьях черного и даурского, молодежь японского журавля по пятам следовала за взрослыми (как на суше, так и в полете). В июле 1997 г. во время авиаучета в Амурской области у 15 успешно размножавшихся пар было 22 птенца или 1,47 молодых на пару (Darman and Andronov, 2011).

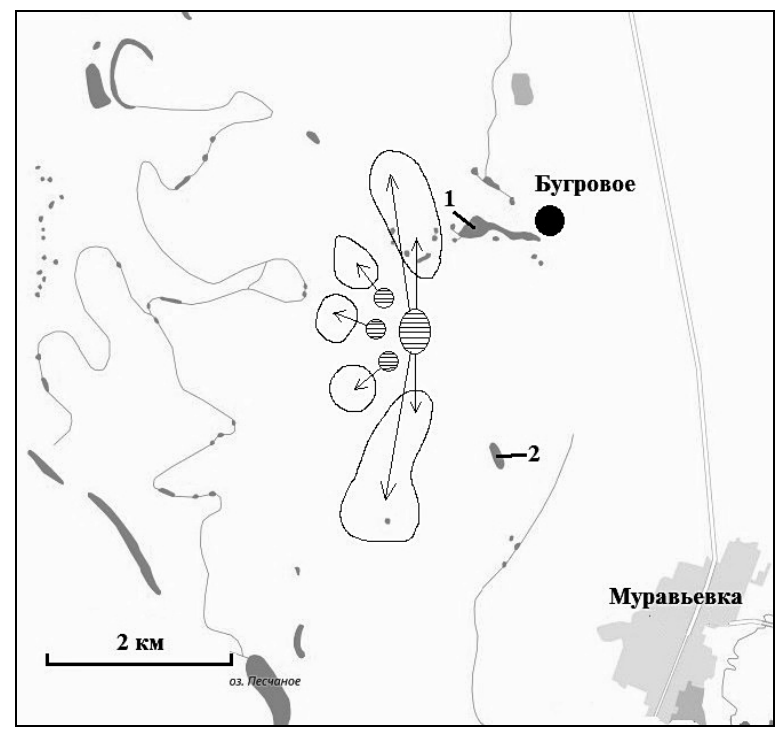

Рис. 12. Места ночевок и кормежек японского журавля в предотлетном скоплении осенью 1992 г.:

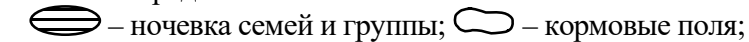
$\rightarrow$ - пути перелета; 1 - оз. Капустиха; 2 - оз. Гальянистое; - стационарный пункт наблюдений

По словам охотоведа Н. Д. Никулина, гнезда были у всех шести пар. В одном случае гнездо погибло от пожара, причина гибели двух других - неизвестна; успешность размножения составила 29,4\%. В 2003-2004 гг. на территории Муравьевского заказника гнездилось 5-8 пар (Darman and Andronov, 2011), а в 2015 г. всего две, одна из которых была с двумя птенцами (Dugintsov, 2015). На низкую численность японских журавлей указывает Vinter (1977, 1979), который для 1974-1976 гг. в пределах Буреинско-Архаринской низменности оценивает ее в 8 территориальных пар (5 гнездящихся).

Величина и динамика групп

Группы японских журавлей встречены 45 раз (рис. 13). Чаще всего отмечены пары, которых мы склонны относить к неудачно размножавшимся птицам (24 встречи или $53,3 \%$ от общего) и семейные группы с 1 или 2 молодыми, доля которых составила $42,2 \%$. Такая обособленность свойственна японским журавлям до самого отлета. Последними покидают территорию семейные группы, встреча которых в ноябре, например, для Архаринской низменности достигает 60\% (Andronov, 2008). Среднее число особей в группе - 2,87 $\pm 1,16$ (n = 45; lim: 2-7; $\left.\mathrm{C}_{\mathrm{v}}=40,5 \%\right)$. Этот показатель в течение периода наблюдений довольно постоянен и не дает представления о миграционном состоянии птиц, которое у двух других видов прослеживается четко. Поэтому интересно сравнить среднее расстояние между отдельными парами и семьями в местах ночевок: $11.09-348$ м ( $\mathrm{n}=5$; lim: 70-1170), $12.09-488$ м ( $=4$; lim: 100-1500), $14.09-343$ м (n = 4; lim: 70-1000), 21.09- 102 м (n = 5; lim: 10- 
300). Эти данные позволяют предположить тенденцию к сокращению расстояний между группами птиц к началу третьей декады сентября.

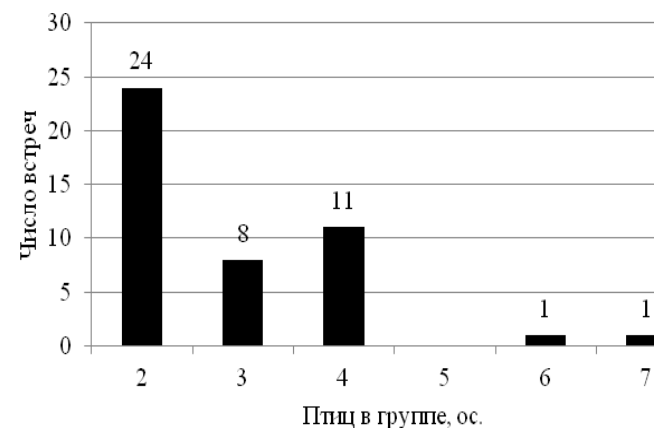

Рис. 13. Встречи групп японского журавля

\section{Вокальная активность}

В отличие от двух других видов японские журавли часто издавали унисональные крики особенно утром и вечером (реже). По трехдневным наблюдениям, утром унисональные серии в среднем состояли из $10,1 \pm 4,5$ криков $\left(\mathrm{n}=24\right.$; lim: 4-20; $\mathrm{C}_{\mathrm{v}}=$ $44,5 \%$ ) и раздавались через 2,7 мин, а вечером - из $11,8 \pm$ 4,0 криков ( $\mathrm{n}=11 ; \mathrm{lim}: 6-18 ; \mathrm{C}_{\mathrm{v}}=34,2 \%$ ) и звучали через 13,2 мин.

Таким образом, изучение осенних скоплений трех видов журавлей показало три различных стратегии поведения птиц, различающихся степенью готовности к миграции.

Наиболее готовыми к миграции были черные журавли. В их скоплении отмечены совместные перелеты, ночевки и кормление взрослых птиц и семей с молодыми. У даурского журавля эта связь менее тесная, однако, к концу наших наблюдений отмечалось увеличение среднего числа птиц в стаях, что свидетельствует о процессе вливания семей в общую группу. Все японские журавли были местными птицами. Семьи и взрослые птицы без молодых весь период наблюдений держались обособленно друг от друга и от других видов журавлей. Эту особенность поведения японских журавлей отмечал на территории парка и Dugintsov (2015).

Характер кормовых перелетов говорит о наиболее дальних расстояниях у черного журавля (несколько километров). По данным Dugintsov (2015), дальность разлета журавлей от мест ночевок до кормовых полей составляет от 1,5 до 12-15 км. Главные факторы, обуславливающие маршруты дневных перелетов журавлей - сроки уборки кукурузы и послеуборочной обработки полей в хозяйствах: чем больше полей кукурузы убрано в хозяйствах, тем чаще журавли разлетаются с мест ночевок в разных направлниях к убранным полям (Dugintsov, 2015).

Даурский журавль предпочитал близлежащие кормовые поля, отстоявшие от мест ночевок до 2,5-3,0 км. Большую часть наших наблюдений японские журавли отмечались в пределах болота, лишь изредка вылетая или даже выходя на поля, примыкающие к нему, и кормясь отдельно от двух других видов. Такие различия, вероятно, обусловлены исходным физиологическим состоянием японского журавля, резкой разницей во внешности и размерах, значительной «остаточной» территориальностью, качественно иным состоянием взаимоотношений в группах «взрослые - молодые», «взрослые - семьи». Общая территория кормления и ночевок у японского журавля, вероятно, определялась предпочтениями птенцов к набору кормов, смена которых на зерновые до конца наблюдений еще не произошла.

\section{Отлет на зимовку}

Отлет на зимовку также происходит поочередно. Все 292 черных журавля улетели двумя группами с 21.09 по 26.09, а с 27.09 в районе наблюдений не учтено ни одной птицы. О сжатых сроках осеннего пролета и его окончании к концу сентября для Архаринской низменности (170 км юго-восточнее) указывают также Andronova and Andronov (2008). Однако в
1992 г. эти авторы наблюдали максимальную длительность осеннего пролета (42 дня). Возможно, отлет журавлей из Муравьевского парка и максимальная интенсивность пролета птиц в сентябре в Архаринской низменности, взаимосвязаны, поскольку обе территории лежат на одном миграционном пути.

К 29.09 все 34 даурских журавля еще оставались в районе наблюдений. В районе г. Уссурийск (Приморский край) окончание пролета даурского журавля отмечено в последней декаде октября (Korobov and Glushchenko, 2008).

Все японские журавли держались здесь до окончания наблюдений. По словам местных жителей в 1991 г. они были в этом районе до 5 ноября (уже по снегу). По данным Pan'kin and Neyfel'dt (1976), проводивших наблюдения в Амурской области, в 1967-1968 гг. последние регистрации птиц были 8.11, а для Приханкайской низменности (600 км к юго-востоку от Муравьевки) Glushchenko et al. (2006) для 1992 г. приводят дату 18.11.

Старт гнездования у этих видов происходит в схожие сроки: третья декада апреля - начало мая (Pankin and Neifeldt, 1976; Vinter; 1983; Flint, 1987; Gil-Weir et al., 2012; Yuxiang et al., 2012; Vinter et al., 2015; Gilber et al., 2016).

Благодаря неравному соотношению размеров и массы у особей этих видов $(1: 1,3: 1,7)$ молодые поднимаются на крыло с очень заметным расхождением по времени: у черных - в 55-60-дневном, у даурских - в 65-70-дневном, а у японских журавлей - в 70-75-дневном возрасте. Таким образом, различия между черным и японским журавлями составляет 2-3 недели. Эта разница и лежит в основе отмеченных отличий в поведении видов в период предотлетных скоплений.

Изучение скоплений журавлей в 1992 г. в Муравьевском парке финансировалось Социально-Экологическим союзом России, чему способствовал С. М. Смиренский. Многолетнее научное, финансовое и эмоциональное мотивирование журавлиных исследований, как и критические замечания к статье осуществлены С. В. Винтером, за что авторы ему искренне благодарны.

\section{References}

Aboimov Y. N. (ed.) (2009). Krasnaya kniga Amurskoy oblasti: Redkie i nakhodyashchiesya pod ugrozoy ischeznoveniya vidy zhivotnykh, rasteniy i gribov [Red Data Book of Amur Region. Rare and threatened animal, plant, and mushroom species]. Blagoveshchensk State Pedagogical University Press, Blagoveshchensk (in Russian).

Amur Bird Project at Muraviovka Park: Report 2014 (PDF Download Available).

Amur Bird Project at Muraviovka Park: Report 2015 (PDF Download Available).

Amur Bird Project at Muraviovka Park: Report 2016 (PDF Download Available).

Andronova, R. S., \& Andronov, V. A. (2008). Prolet chernykh zhuravley v Arkharinskoy nizmennosti [The passage migration of Hooded Crane in Arkhamskaia Lowland]. Zhuravli Evrazii (biologiya, rasprostranenie, migratsii) [Eurasian Cranes (biology, distribution, migrations)]. Moskovskiy zoopark, Moscow (in Russian)

Arkhiv pogody po gorodam SNG (XIX i XX veka) [Weather archive for SIC cities (XIX and XX centuries)]. (in Russian).

Butler, M. J., Harris, G., \& Strobel, B. N. (2013). Influence of whooping crane population dynamics on its recovery and management. Biological Conservation, 162, 89-99.

Butler, M. J., Metzger, K. L., \& Haris, G. M. (2017). Are whooping cranes destined for extinction? Climate change imperils recruitment and population growth. Ecology and Evolution, 7(8), 2821-2834.

Darman, Y. A., \& Andronov, V. A. (2011). Status yaponskogo zhuravlya v rossiyskoy chasti basseynv reki Amur [Status of Red-crowned Crane in the Russian part of Amur River]. Zhuravli Evrazii (biologiya, rasprostranenie, migratsii, upravlenie) [Eurasian Cranes (biology, distribution, migration, management)], 4, 226-232 (in Russian).

Dugintsov, V. A. (2015). Nablyudeniya za osenney migratsiey zhuravley v Murav'evskom parke [Observations over the crane autumn migration in the Muraviovka Park] (in Russian). 
Flint, V. E. (1987). Semeystvo Zhuravlinye [Ralidae Family]. In: Birds of the USSR. Ralidae, Griuformes. Kuroobraznye, Zhuravleobraznye. Leningrad (in Russian).

Gilber, M., Buuveibaatar, B., Fine, A. E., Jambal, L., \& Strindberg, S. (2016). Declining breeding populations of White-naped Cranes in Eastern Mongolia, a ten-year update. Bird Conservation International.

Gil-Weir, K. C., William, E., Grant, W. E., Slack, R. D, Wang, H.-H., \& Fujiwara, M. (2012). Demography and population trends of Whooping Cranes. Journal of Field Ornithology, 83(1), 1-10.

Glushchenko, Y. N., Shibnev, Y. B., \& Volkovskaya-Kurdyukova, E. A. (2006). Ptitsy. Pozvonochnye zhivotnye zapovednika "Khankayskiy" i Prikhankayskoy nizmennosti. Birds. Vertebrates of "Khankayskiy" Reserve and Caspian Plain. Vladivostok (in Russian).

Gorlov, P. I. (1998). Predmigratsionnoe skoplenie serykh zhuravley na Tsentral'nom Sivashe. Pre-migratory flocks of Gray cranes in Central Sivash. Branta, 1, 103-110 (in Russian).

Harris, J., \& Mirande, C. (2013). A global overview of cranes: Status, threats and conservation priorities. Chinese Birds, 4, 189-209.

Heim, W., \& Suanjak, M. (2016). Siberian Crane Leucogeranus leucogeranus numbers on the increase at Muraviovka Park, Far East Russia. Birding Asia, 25, 44-46.

Higuchi, H., Pierre, J. P., Krever, V., Andronov, V., Fujita, G., Ozaki, K., Goroshko, O., Ueta, M., \& Kespayk, Y. E. (1989). Izuchenie sezonnykh skopleniy. Metodicheskie rekomendatsii po izucheniyu zhuravley. [Study of seasonal congregations. Methods of cranes' study]. Tartu (in Russian).

Korobov, D. V., \& Glushchenko, Y. N. (2011). Kal'nitskaya. Migratsiya daurskogo zhuravlya na Khankaysko-Razdol'nenskoy ravnine (Primorskiy kray) [Kalnitskaia maigration of White-naped crane in Khankaysko-Razdol'nenskaia Valley (Primosrkiy Krai)]. Zhuravli Evrazii (biologiya, rasprostranenie, migratsii, upravlenie) [Eurasian Cranes (biology, distribution, migrations, managamane)], 4, 335-344 (in Russian).

Liying, S., \& Hongfei, Z. (2012). Status, threats and conservation needs for the continental population of the Red-crowned Crane. Chinese Birds, 3(3), 147-164.

Marsh, D. M., \& Trenhan, P. C. (2008). Current trends in plant and animal population monitoring. Conservation Biology, 22, 647-655.

Nosachenko, G. V., \& Smirenskiy, S. M. (2008). Struktura i raspredelenie nochevok zhuravley v Murav'evskom parke, Amurskaya oblast'. [Structure and distribution of crane roosting in Muraviovka Park, Amur regions]. Zhuravli Evrazii (biologiya, rasprostranenie, migratsii) [Eurasian cranes (biology, distribution, migrations)], 3, 375-383 (in Russian).

Pan'kin, N. S., \& Neyfel'dt, I. A. (1976). Yaponskiy zhuravl' v Amurskoy oblasti. Redkie, ischezayushchie i maloizuchennye ptitsy [Red-crowned crane in Amur region. Rare, distinct, and understudied species]. Trudy Okskogo Gosudarstvennogo Zapovednika, 13, 86-92 (in Russian).

Smirensky, S., \& Mita, N. (2004). Using a remote technology in conservation: Satellite tracking white-naped cranes in Russia and Asia. Conservation Biology, 18, 136-147.

Sun, K.-J., Hijikata, N., Ichinose, T., \& Higuchi, H. (2015). The migration flyways and protection of Cranes. China Global Environmental Research, 19, 113-121.

Vinter, S. V. (1977). Gnezdovanie yaponskogo zhuravlya v Srednem Priamur'e [Breeding of Red-crowned crane in the Middle Amur area]. Bulletin MOIP, 6, 39-53 (in Russian).

Vinter, S. V. (1979). Yaponskiy zhuravl' - zhemchuzhina Azii [Red-crowned crane is the Asian Pearl]. Priroda, 4, 96-100 (in Russian).

Vinter, S. V., \& Gorlov, P. I. (2003). Razmnozhenie serogo zhuravlya, Grus grus, na vostoke Ukrainy v zavisimosti ot pogodnykh usloviy [Effect of weather conditions on the breeding pattem of Gray crane in Eastern Ukraine]. Vestnik Zoologii, 37(1), 49-59 (in Russian).

Vinter, S. V., Andryushchenko, Y. A., Gorlov, P. I., \& Shibnev, Y. B. (2015). Ekologiya i povedenie razmnozhayushchikhsya chernykh zhuravley v Severo-Zapadnom Primor'e [Ecology and behavior of breeding Hooded cranes in North-Eastem Primorye]. Zhuravli Evrazii (biologiya, rasprostranenie, razvedenie) [Eurasian cranes (biology, distribution, migrations)], 5, 33-67 (in Russian).

Wang, Z.-Q., Li Jiang, X.-Z., Liu, D.-G., \& Zhang, H. C. (2014) Spatial distribution of the red-crown crane population in Zhalong wetlands over the last 30 years. Journal of Ecology and Rural Environment, 30, 27-31.

Yuxiang, L. I., Changzhan, S., Yucheng, Y., Xiaojing, L. I., Fengli, L. I., Jie, H., \& Xiuli, H. (2012). Monitoring population dynamics of the migratory Redcrowned Crane (Grus japonensis) at Shuangtaihekou National Nature Reserve, Northeastern China, from 1991 to 2012. Chinese Birds, 3(3), 225-229.

Zhou, D., Xia, X., Xu, W., Zhang, H., Qian, Z., Gao, J., Wang, Z., \& Jiang, M. (2016). A growing captive population erodes the wild Red-crowned Cranes (Grus japonensis) in China. Avian Research, 7, 22. 